\title{
TCOM \\ Explainers of science centres and museums: a study on these stakeholders in the mediation between science and the public in Brazil
}

\section{Chrystian Carlétti and Luisa Massarani}

\begin{abstract}
In this paper, we investigate who are the explainers who work is Brazilian science centres and museums. We used an online survey, which was answered by 370 people from 73 institutions out of a group of 200 scientific and cultural centres. Our results indicate that most of these professionals are young people between 18 and 25 years old, they hold a high school certificate or are attending university, and they have been working in this field for less than five years. Only a fifth declared that they had done professional training before starting their activities; about $60 \%$ said that they are not prepared to attend to disabled visitors. We believe that our study will improve the practice of science communication, contributing to the creation of training and professional courses.
\end{abstract}

Keywords

Introduction
Mediation; Science centres and museums; Science communication; Explainer
In the last few years, activities related to science communication have boomed in Brazil and the number of scientific and cultural institutions has increased.

However, there is no precise information about the number of science centres and museums in Brazil. Since 2006, the Associação Brasileira de Centros e Museus de Ciência - ABCMC (Brazilian Association of Science Centres and Museums), the Museu da Vida (Museum of Life) and the Casa da Ciência (House of Science) have carried out a survey about these institutions. Although the survey is not exhaustive, the results are available in Guia de Museus e Centros de Ciência [Brito, Ferreira and Massarani, 2009] (Guide to Science Centres and Museums), which has led to the creation of a list of such institutions. According to this guide, in 2009 there were less than 190 scientific and cultural institutions dedicated or potentially closely connected to science communication, such as museums, botanical gardens, zoos, aquariums, planetariums and environmental parks, nearly twice the figure identified three years before. Moreover, according to a national survey $8.3 \%$ of the Brazilian population declared visiting a science museum [Ministério da Ciência e Tecnologia, 2010]. This figure is less than half of the average registered in the European countries, and it has doubled since the previous research carried out in 2006 , when it was about $4 \%$. This scenario indicates that science museums are acquiring an increasingly important role within Brazilian society. 
Due to the increased number of scientific and cultural institutions, the demand for professionals, including explainers, to work there also increased. Their main task is to facilitate visitors' experience by encouraging them to actively engage in and think about the exhibition [Rodari and Xanthoudaki, 2005].

According to Zana [2005], mediation can be traced back to the 17th century in the curiosity cabinets (the starting point of science centres and museums), in which there were already people carrying out demonstration and experiments, acting as a bridge between the exhibits and the public. However, it was only in 1920 that, inspired by the experience of the Deutsches Museum, explainers started to be part of the staff of science museums and introduced a new pedagogical approach. Also referred to as educators, entertainers, supervisors, guides, attendants, anfitriones, etc., they play very important roles within science centres and museums. Falk and Dierking [2000] highlight their key role by stating that the "Sociocultural mediation, either direct or indirect, plays a critical role in personalizing the museum experience for visitors, facilitating their efforts to learning and find meaning". We can think of explainers as "the human interface between the museums' collections, the knowledge and culture that are represented, and the visiting public" [Tran, 2008]. Rodari et al. go further within this definition when considering explainers as "the only 'museum artifact' which is really bi-directional and interactive" [Rodari and Merzagora, 2007].

Considering the different roles they have in scientific and cultural institutions, their job is not a simple or easy task. According to Costa, mediation requires

"a deep scientific knowledge and confidence to challenge the visitor to put forward his or her own ideas and then build upon those ideas; it requires enough familiarity with science and technology to be able to "forget" about equations and standard formulations, and to be able to really talk science with the visitors instead" [Costa, 2005].

Explainers should never act as an intellectual authority suggesting an absolute truth; they need to pay attention to visitors' opinions, doubts and comments in order to include them into their speech [Ruiz-Funes, 2008]. However, in order to act as a explainer, it is crucial to have attended training or professional courses, or have relevant qualifications, because this activity has such specific aspects, that many still do not know or are unable to mediate a scientific exhibition. As Mora [2007] put it, "in order to carry out their task successfully, explainers need to be trained by the museum they work for, so that they feel part of it and can develop a personality that is fit for purpose", so explainers would be more enthusiastic about their job, and would evoke enthusiasm in visitors themselves [Martin and Tamez, 2008].

In Europe, there are initiavies to improve the way explainers are trained. Projects such as DOTIK (http:/ / www.dotik.eu), PILOTS (Professionalisation in Learning Technology and Science, http:/ / www.thepilots.eu) and THE group (Thematic Humam Interface and Explainers group of Ecsite, http:/ / medialab.sissa.it/THE) have focussed on better understanding the practices of mediation, besides creating strategies, dynamics and training courses aimed to help explainers learn about and reflect on their work.

In Brazil, there are initiatives that are or were dedicated to the training of explainers. An example is the continuing professional development course in 
Mediation in Science Centres and Science and Technology Museums regularly organized by Espaço Ciência InterAtiva (InterActive Science Space) of the Rio de Janeiro Federal Institute of Education, Science and Technology (Instituto Federal de Educação, Ciência e Tecnologia do Rio de Janeiro - IFRJ) and delivered by professionals from different scientific and cultural institutions of Rio de Janeiro. Another example is the Study and Research Group for Informal Education and Science Communication (Grupo de Estudo e Pesquisa em Educação Não Formal e Divulgação em Ciência - Geenf) that promotes a continuing professional development course for the training of meditators at São Paulo University (USP) and published the book entitled Educação em Museus: a mediação em foco [Marandino, 2008]. The literature also presents other reports about the experience of training courses for explainers organized in Brazil [Bonatto, Mendes and Seibel, 2007; Ferreira et al., 2008; Lima and Pereira, 2010; Moraes et al., 2007; Ribeiro and Frucchi, 2007; Gomes, 2013].

In 2008, in addition to mediation courses, the "First South American Workshop of Mediation in Science Museums and Centres and School of Mediation in Science Museums and Centres" took place. This event aimed to reflect on the practice of mediation and the training of explainers, and was followed by a second edition organised in December 2012. However, considering the number of Brazilian scientific and cultural institutions and the size of the country, such initiatives have been sporadic and confined to limited geographical areas.

Another important issue is about the tasks attributed to explainers in science centres and museums. According to [Mora, 2007], these professionals "carry out different functions from an international point of view". "Not only do they take care of the public (...), but they also participate in the so-called pedagogical areas, such as the museums' laboratories".

In the Brazilian context, this stakeholder is particularly important, because various activities offered by these institutions are based on human mediation. Nonetheless, there are few studies about these professionals who are at the interface between science and the public in Brazilian science centres and museums. As far as we know, in Brazil there is no study that addresses this topic from a national perspective. In our study ${ }^{1}$ we aim to fill in this gap. We hope to contribute to the consolidation of strategies for the training of these professionals who mediate between science and society in scientific and cultural institutions.

In this paper we aimed to carry out a quantitative survey to obtain a general overview of the professionals who work as explainers in the interface between science and visitors in scientific and cultural institutions, their qualifications, how they were trained, their thoughts about mediation, their tasks as explainers, among other aspects. We included in 'scientific and cultural institutions' interactive science centres/museums, natural history museums, planetariums, zoos, botanical gardens, aquariums and similar bodies.

In order to collect our data, we had as starting point a European study carried out through the DOTIK project. Funded by the European Commission between 2004

\footnotetext{
${ }^{1}$ This study is part of a research project supported by the National Council for Scientific and Technological Development (CNPq).
} 
and 2007, this project aimed to work on theoretical knowledge, assessment techniques and new tools to train explainers to increase their dialogue with visitors. Moreover, it aimed to encourage explainers, engaging them in the assessment practices of their institutions and inclusive processes, so that they could turn into ambassadors of visitors' needs and concerns at the scientific institutions where they would often continue their careers. The project was organised by the International School of Advanced Studies - SISSA (Italy) and three science centres, Immaginario Scientifico Science Centre (Italy), The House of Experiments (Slovenia) and AT-Bristol Science Centre (United Kingdom), and created experimental training systems. We paid particular attention to a specific aspect of DOTIK: a survey on explainers of European museums. DOTIK used a questionnaire to gather data about the professional situation of explainers, their professional expectations, the selection criteria and training strategies applied in the different European institutions. The questionnaire was distributed during the European Network of Science Centres and Museums (ECSITE) annual conference held in Finland in 2005 [Rodari et al., 2006].

On the basis of the questionnaire used by the DOTIK project, we created a survey to find out more about the explainers who work in Brazilian scientific and cultural institutions. We also took account of Paola Rodari's suggestions, the researcher at SISSA who led the DOTIK project. Our questionnaire included 43 questions, divided in four sections. The questions used for the analysis are listed below and these results are discussed afterwards:

- "About you", including questions of a personal nature, such as age, gender and education;

- What studies did you do?

口 What is your date of birth?

$\square$ What is your gender?

- "About the place where you work", with questions about the scientific and cultural institution explainers belong to, with information about these institutions, such as geographical location, opening date, target audience, purpose, opening times, etc.

- What scientific and cultural institution do you work for?

- What state is it located in?

- What is the target audience?

- Are there any activities for people with special needs?

- "About the activities offered by the scientific and cultural institution where you work", a section where we wanted to find out what activities are offered by the institution, if there has been an increase in the number of these activities and in what activities the explainers are involved.

- What types of activities are offered by the scientific and cultural institution you work for?

- What activities do you take part in? 
- "About your professional practice", a section where we wanted to find out about professional practices, asking questions about job titles, tasks, how long the professionals have been working in the field, how they are connected with the scientific and cultural institution, what they believe to be important in their professional practice, what their roles are as explainers, if they had an initial and/or continuing professional training, if they are involved in the preparation of the exhibition content and activities, if they feel prepared to attend to visitors with special needs, etc.

$\square$ What is the job title of those who attend to visitors in the place where you work?

- What are their tasks in the place where you work?

- How long have you been working in a scientific and cultural institution?

口 What options better describe your current professional situation?

口 In your view, what is your role in your work place?

- How were you trained before starting the activities with visitors?

$\checkmark$ When exhibitions and activities are designed, are your ideas and opinions considered?

We carried out the survey using an online questionnaire, posted on a web page (www.mediadoresdobrasil.com), from September 2012 to January 2013. This web page was created by a web designer, who made the questionnaire dynamic and easy to answer. The home page showed a welcome message and included a âĂ $\breve{Y s t a r t a ̂ A ̆ Z ́ ~ b u t t o n ~ t h a t, ~ i n ~ l i n e ~ w i t h ~ t h e ~ r e q u i r e m e n t s ~ o f ~ t h e ~ E t h i c s ~ C o m m i t t e e, ~}$ took to a page that showed the Informed Consent Term. The explainer had to accept the term to access the questionnaire.

In order to spread the voice on the web page with the questionnaire and encourage explainers to answer, we phoned ${ }^{2}$ each scientific and cultural institution listed in the guide Centros e Museus de Ciência do Brasil 2009 [Brito, Ferreira and Massarani, 2009]. We also identified a few science museums that were not listed in the guide, and included them into our sample. As there is no detailed information about the number of explainers who work in Brazil, we took the opportunity to ask for the number of these professionals in each organization we contacted. In total, we contacted 212 institutions, of which 22 had not been listed in the guide. We also published our study/questionnaire on the website of Associação Brasileira de Centros e Museus de Ciência - ABCMC (Brazilian Association of Science Centres and Museums), distributed it to the stakeholders through other means of communication and by e-mail.

Among the 212 scientific and cultural institutions identified in this study, 9 do not work with mediation and three are closed. Therefore, our group was made of 200 Brazilian scientific and cultural institutions. In total, explainers of 73 institutions answered the questionnaire, thus obtaining the participation of $36.5 \%$ of science

\footnotetext{
${ }^{2}$ We would like to thank Ana Paula Trindade for her valuable collaboration at this stage of the project.
} 
museums and centres previously identified. For comparison purposes, the response percentage is higher than the one obtained by the DOTIK project, which registered the participation of 29 institutions from 12 European countries [Rodari et al., 2006].

We asked the 200 institutions to let us know the number of explainers who work there: 117 gave us this information, amounting to 1,374 explainers. The respondents in the remaining 83 scientific and cultural institutions stated that they do not know the number of explainers working there or that they were not allowed to disclose such information. In other words, in Brazil the total number of explainers who work in scientific and cultural institutions is unknown.

In our study, we obtained 370 valid and answered questionnaires. Considering the estimated total number of explainers in the museums that informed us about the number of their attendants, and inferring the number of the remaining museums, we estimate that our response to the questionnaire is $26.9 \%$. Taking account of the standard response for research work carried out online, which is between $7 \%$ and 13\% [Freitas, Janissek-Muniz and Moscarola, 2004], we obtained a considerable number of responses.

In Brazil, most of the scientific and cultural institutions are located in the south eastern region (59.8\%), which is made of the federal states of Espírito Santo, Minas Gerais, Rio de Janeiro and São Paulo where there are $42 \%$ of the population (approximately 80 millions), with the highest pro capita income in the country (about US\$ 15,534.00 [Instituto Brasileiro de Geografia e Estatística (IBGE), 2010]). Figure 1 shows the distribution by federal state of the scientific and cultural institutions and institutions where explainers responded to the questionnaire, which matches, to some extent, the uneven distribution of such institutions in the country.

The highest level of participation was registered in the south eastern region. However, if we are to think in terms of relative numbers, we will notice that the larger participation was that of Pará where nearly $67 \%$ of its institutions contributed to this research. The federal states of São Paulo and Rio de Janeiro had about $27 \%$ and $42 \%$ of participation respectively.

Following the same trend of geographical distribution of scientific and cultural institutions, $71.6 \%$ of the respondents are located in the south eastern region of the country as shown in Figure 2. The state that had the highest presence in the survey was Rio de Janeiro (28.1\% of respondents), followed by São Paulo $(22.7 \%)$ and Minas Gerais (16.2\%). However, it was not possible to do a relative calculation of explainers, because, as mentioned earlier, there is no total number of these professionals for each centre.

As for the types of scientific and cultural institutions that took part in the survey, we obtained the following distribution: 47 interactive science centrers/museums, of which 7 have a planetarium, three itinerant science museums, four natural history museums, 5 planetariums, 5 zoos, 7 botanical gardens and two history museums.

We reflected on whether there was a relation between the type of scientific and cultural institution and the way those who attend to the visiting public are named. Data suggests that there is no direct and/or close relation, but in some instances 


\section{Number of Institutions by Federal State}

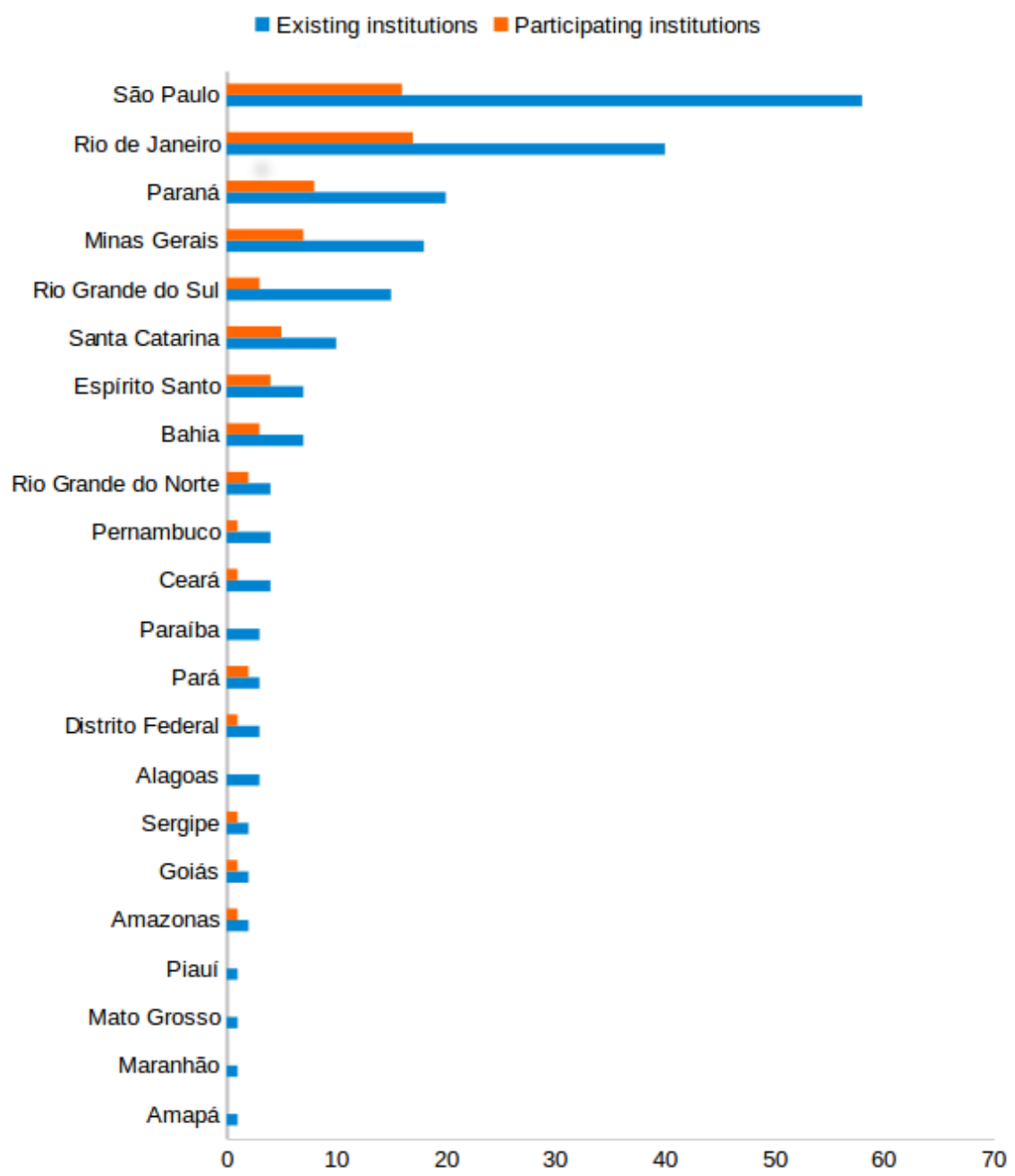

Figure 1. Shown in blue is the number of scientific and cultural institutions located in each federal state $(n=209)$ noted down when the survey was distributed to the explainers. Shown in orange is the number of scientific and cultural institutions that responded to the survey and are distributed by federal unit $(n=73)$. The five federal states that do not have scientific and cultural institutions were not included in the above graphic.

there is a certain pattern. In interactive science centres and museums these professionals are, in the majority of the cases, named supervisors or explainers; in botanical gardens, guides or educators; in zoos, supervisors or educators, and in planetariums supervisors or planetarium workers. We also tried to associate the way they are named with the state where they work, and, in this case, there is no direct relation nor predominance in the trend.

Among explainers, there are slightly more women (56.2\% of the respondents) than men $(43.8 \%)$. While comparing this data with other studies, we observed that the presence of women in the world of scientific dissemination seems to be a known trend: in Europe, the number increases to 61\% [Richard, 2010] and among Brazilian science journalists $66.2 \%$ of the respondents to a survey were women [Massarani, Bauer and Amorim, 2013]. 


\section{Number of responses by state}

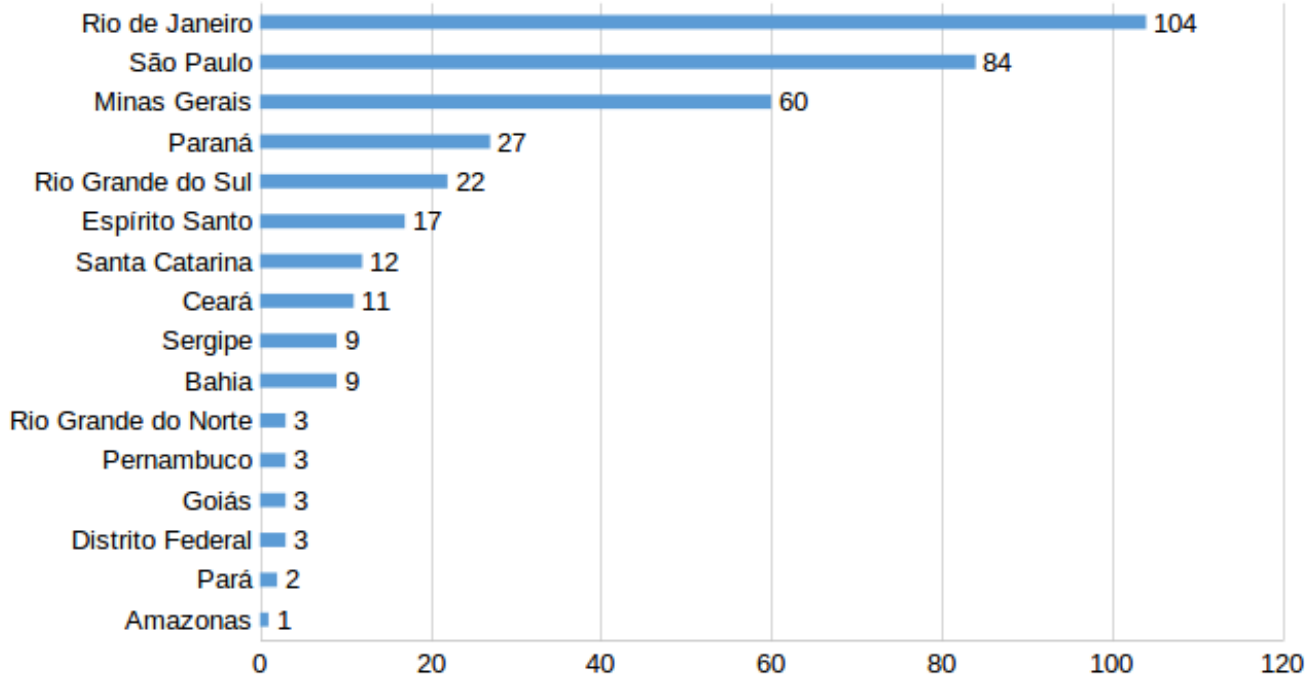

Figure 2. Distribution of the number of responses by state $(n=370)$.

Data also indicates that there is a higher number of young people between 18 and 25 years $(63.5 \%)$ who work as explainers in scientific and cultural institutions (Figure 3).

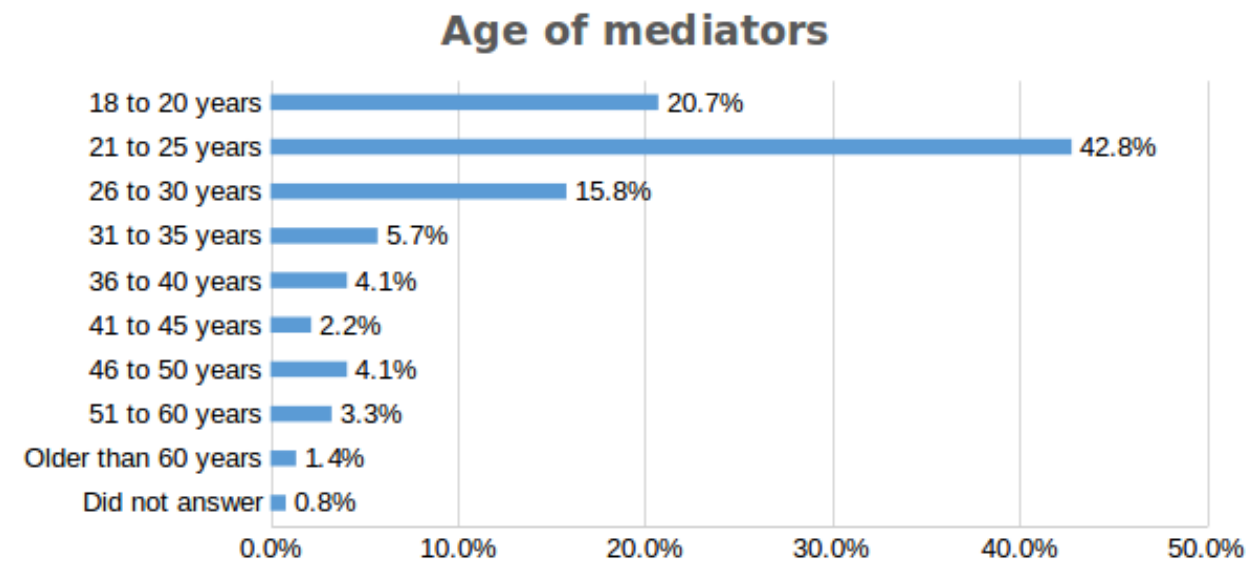

Figure 3. Distribution of explainers by age $(n=370)$.

As shown in Figure 4, 60\% of the explainers have completed high school or are attending university. Out of the total of respondents, 138 (37.2\%) already completed a university course.

About half of the explainers holding a university degree (46.4\%) have studied exact and natural sciences; $34.1 \%$ social sciences and humanities; $16.7 \%$ medicine and health sciences; $1.4 \%$ engineerig and technology and $1.4 \%$ agricultural sciences.

Within the group of 138 who stated that they had already completed their university course, we observed that $45 \%$ have further education: $31(22.5 \%)$ of the respondents are specialised in a certain field; 24 (17.4\%) have completed a master course and 7 (5.1\%) hold a PhD. 


\section{Mediators' education}

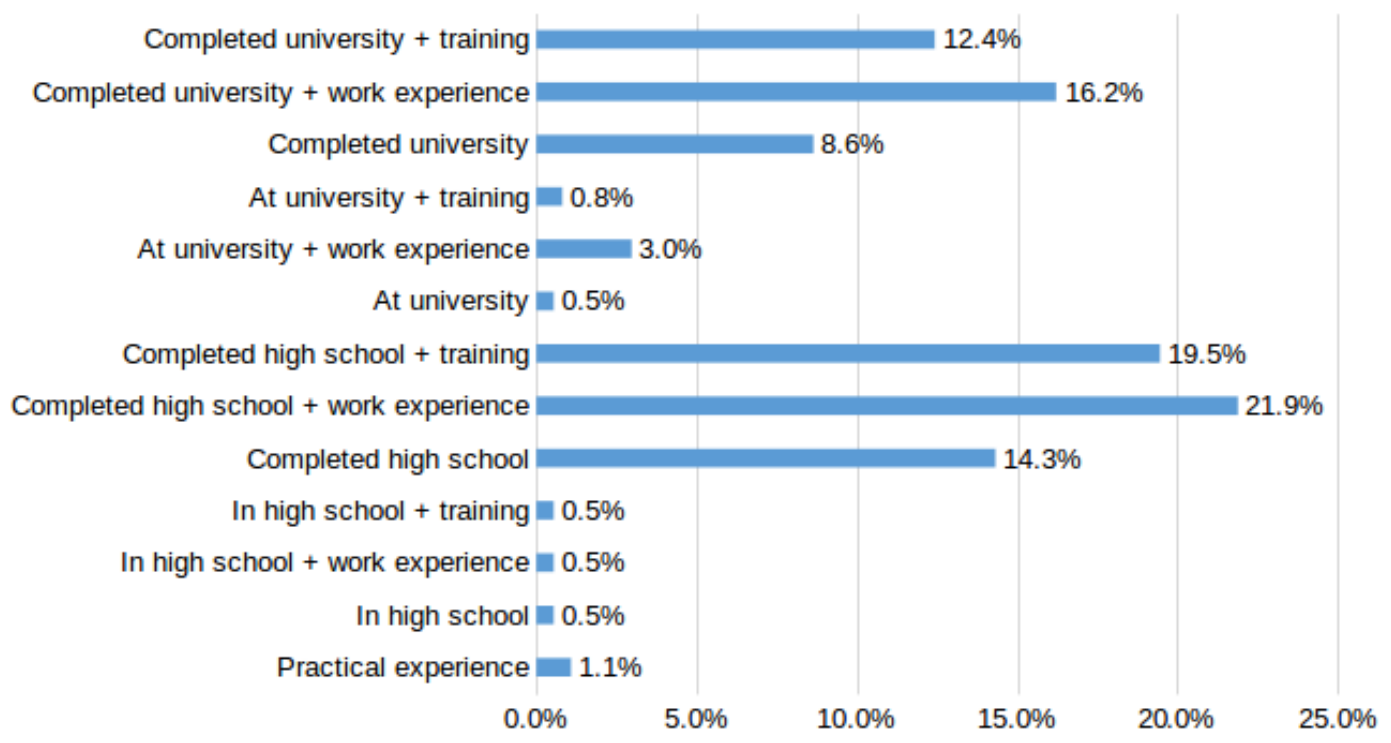

Figure 4. Level of education of explainers $(n=370)$.

As shown in Figure 5, a considerable amount (60.6\%) of those who answered the questionnaire receive a scholarship to work in scientific and cultural institutions. In other words, they are affiliated to an institution that does not offer employment rights, such as paid time off, pension and health insurance and tend to last a fixed period of time. Less than a third is more closely connected with an institution, with $65(17.6 \%)$ having carteira assinada (a legally and officially recognised job that guarantees employment rights in Brazil) and 47 (12.7\%) are public sector workers (with employment stability and rights).

\section{Mediator's working relationship with the institution}

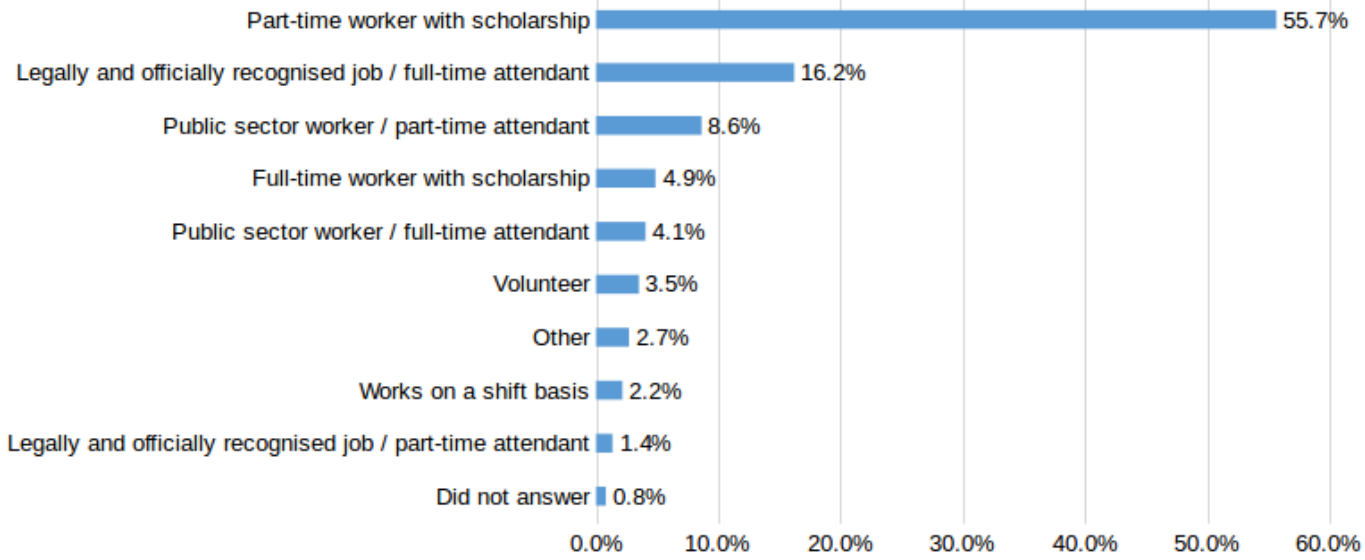

Figure 5. Explainers' working relationship with the scientific and cultural institution they work for.

When checking the relationship between legally and officialy recognised jobs and the level of education of 65 explainers who have a good employment situation, we noticed that 23 have completed high school, 18 hold a university degree, 11 are specialised in a certain area, 10 have a master degree and just two hold a PhD. This 
situation changes slightly when we consider public sector workers: 15 are attending a specialised postgraduate course, followed by graduates (12) and those with a master degree (10). In each group, there are 5 people with a PhD and 5 with a high school certificate. As for the level of education, we observed that there are more explainers with studies in either exact sciences and natural sciences or in social sciences and humanities (17 and 18, respectively, have a legally and officially recognised job; 19 and 15, respectively, work in the public sector). The data we gathered does not allow us to accurately analyse the reason why there are so many explainers with just a high school certificate and few public sector workers in the same situation.

It is worth paying attention to the fact that $84.9 \%$ of explainers stated that they have been working in this field for less than 5 years. The others declared that they have been working in the field for a period between 6 and 10 years $(7.6 \%)$, for 11 to 15 years $(3.5 \%)$ and for more than 15 years $(4.1 \%)$.

The majority of those who answered our questionnaire (61.6\%) declared that they did not attend a training course before they started working in science museums and centres and received instructions from the explainers who had been working there longer. Slightly more than a fifth $(23.8 \%)$ declared that they had attended a professional training course before working as explainers, $15.1 \%$ attended a course that lasted more than 12 hours and that had been organised by their own centre, $7.8 \%$ attended an internal course that lasted less than 12 hours and $0.8 \%$ did an external course (organised by another body). However, more that two thirds $(71.1 \%)$ declared that they attended a professional training course that ran in parallel with their work, with the purpose of improving their performance after starting the activities.

With regards to what they think is important that explainers do when welcoming visitors, the respondents believe that it is of paramount importance for a good explainer to adapt to the public (66.7\%), draw visitors' attention (56.4\%) and encourage dialogue about the topic in question (42.1\%). When asking them what they do when putting these into practice, the majority declared that they adapt to the public $(64.5 \%)$, try and catch the visitors' attention $(49.7 \%)$ and demonstrate principles and pheomenon to the public (39.1\%).

Explainers also stated that their main concerns regarding their work are that of awakening visitors' curiosity (87\%), teaching as much as possible $(62.4 \%)$, showing confidence and assertiveness (58.1\%), keeping their work environment in good order $(47.8 \%)$, to entertain visitors $(34.3 \%)$ and to explain the use of as much equipment as possible (28.4\%).

Regarding the tasks explainers do, guiding the public within the organization $(84.3 \%)$, being a bridge between the public and the exhibition $(83.5 \%)$ and welcoming visitors $(77.3 \%)$ are the main functions they declared, as shown in Figure 6. 


\section{Roles of mediators}

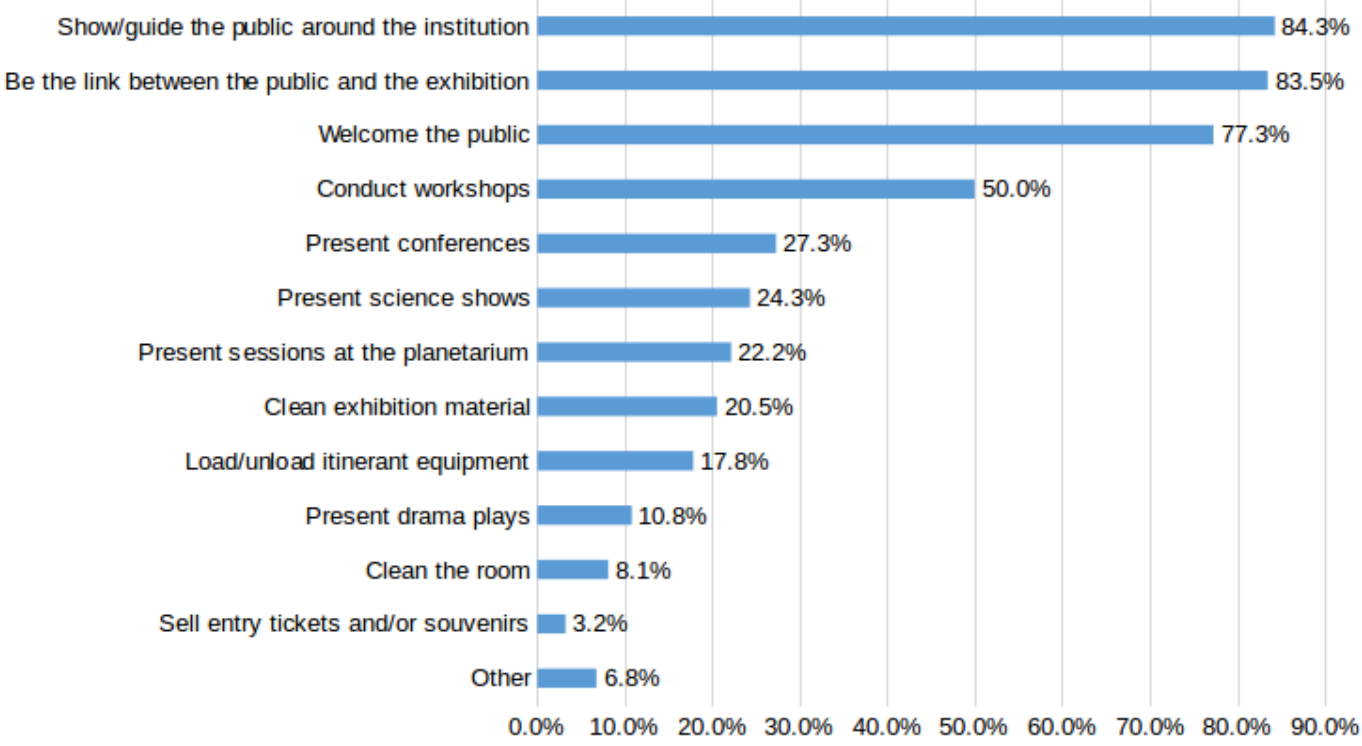

Figure 6. Distribution of tasks attributed to explainers $(n=370)$. Each respondent could opt for as many answers as those that most closely described their role, hence the total sum exceeds $100 \%$.

About $60 \%$ of explainers declared that they do not feel prepared to take care of disabled people. Those who feel able to take care of this group of visitors (just 138 explainers) were asked what type of disability they were able to address. Results are shown in Figure 7:

\section{Type of disability in the public with which you are able to deal}

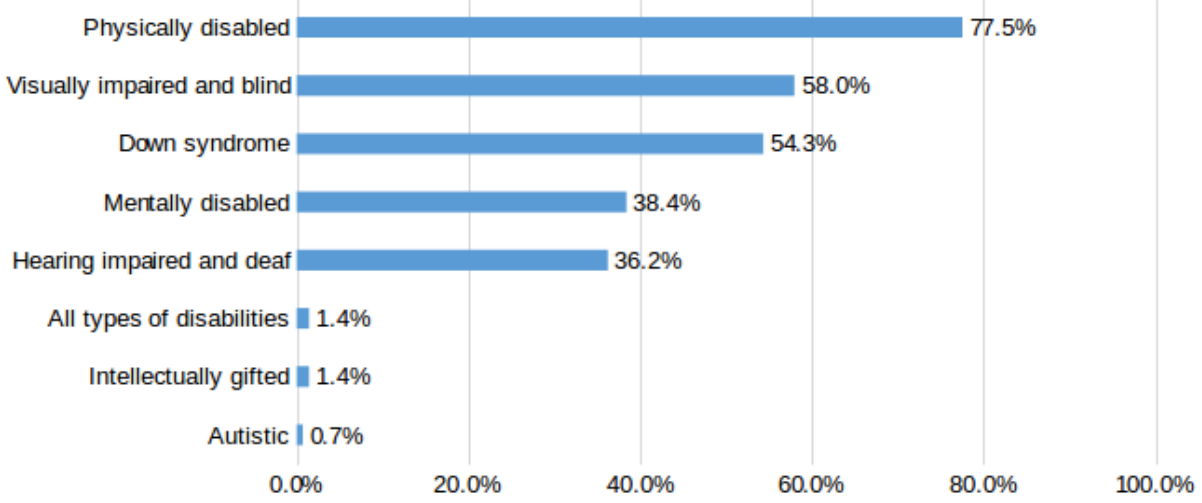

Figure 7. What type of disability are you prepared to take care of $(n=138)$ ?

Our research shows that most of the professionals who mediate in Brazilian scientific and cultural organizations declared that they are safisfied or completely safisfied with their work (86.8\%). Few stated that they were not satisfied (just 6 explainers), however, none of them said that they wanted to stop working in this field. Moreover, a considerable number $(62.7 \%)$ declared that they want to continue to work in science communication and they would recommend the career of explainer/scientific communicator to a young student (91.1\%). 
Different institutions worldwide consider the work of explainers to be important for the good functioning of science centres and museums, as well as for the improvement of the communication with the visiting public [Rodari and Xanthoudaki, 2005; Costa, 2005; Mora, 2007; Martin and Tamez, 2008; Marandino, 2008]. Brazil is no exception. Out of the 209 scientific and cultural institutions listed in the Guia de Centros e Museus de Ciência no Brasil (Guide of Science Centres and Museums in Brazil), 200 have explainers as part of their staff. However, despite the importance attributed to the work they carried out, Brazilian academic literature about them is still at its very beginnings and is geographically uneven. We could not find any studies that focussed on the profile of these professionals from a national perspective - a gap we tried to fill with this work.

Brazil is a multicultural country, with a vast territory, whose population is unevenly distributed and has different levels of economic development. For example, the south eastern region includes four of the 27 federal states of the country, but is host to $42 \%$ of the population (approximately 80 millions of people), and has the highest pro capita income, accounting for US\$ 15,534.00 [Instituto Brasileiro de Geografia e Estatística (IBGE), 2010]. These imbalances are found in the data gathered for our research, as $59.8 \%$ of the Brazilian scientific and cultural institutions are located in this area. Indeed, we anticipated a greater concentration of answers from this area of the country, as we observed in our study: 71.6\% (265 explainers) of those who answered the survey. This uneven distribution of the institutions and the low number of answers obtained in some states made it impossible for us to carry out a deeper comparative analysis between the data we gathered and the data gathered in each Brazilian state. However, this is not a shortcoming of our study only. Often, research work carried out on a national scale does not offer comparisons between the states, as it would require a significant increase in the number of respondents, which would result in higher costs.

Being a explainer in Brazil (and elsewhere in the world) is challenging. On the one hand, it results from the requirements of one's own tasks as a social player, which are varied and require knowledge and preparation. On the other hand, it is a consequence of the way explainers are connected with their own institutions and of the low financial remuneration they receive for developing mediation activities. In total, $60 \%$ of the respondents declared that they have a precarious working relationship with their employer, created through scholarships. This shows that explainers' work is not regarded as a profession. As Tran [2008] put it, although in Europe the discussion about the professionalisation of educators in science centres and museums (which explainers belong to) has been ongoing for many decades, the lack of a "common language" between institutions and a definition of what knowledge and skills are required, as well as the lack of an educational framework of professional training, are the obstacles jeopardising the professionalisation of educators of science centres and museums. It is a fact that Brazil lacks a common language. Although customer service is a task that all explainers involved in this research do, we observed that each institution does or does not attribute other duties to its explainers. This might be justifiable on the basis that each institution has got unique characteristics and there are cultural differences between regions. Therefore, there is no common identity, thus leaving the professionalisation of explainers in Brazil increasingly more remote from reality. 
In the Brazilian context, most explainers are young people between 18 and 25 years, who completed high school or are attending university and work as explainers on a temporary basis. Mediation activities in Brazilian science museums and centres seem to be aimed to the training of these young people, and potentially can raise awareness among them about the importance of enagaging society in scientific and technological topics. In the meantime, additional studies would be required to understand what these young people need, from a professional point of view, after leaving the museum. For comparison purposes, the connection that explainers have with their own institutions seems to be fragile in Europe too. According to the answers obtained within the PILOTS project, about half of the explainers have precarious contracts [Richard, 2010], and within the DOTIK project $41 \%$ of explainers were students who worked as explainers on a temporary basis and $34 \%$ were paid on an hourly basis, which, in general, according to them, meant low salaries [Rodari et al., 2006]. However, the precarious connections with their institutions do not discourage them from working in this field. Those who answered our questionnaire have a high level of job satisfaction. Similarly, European explainers consider mediation a rather rewarding experience, as the skills and knowledge they acquire are extremely valuable when becoming researchers [Rodari et al., 2006].

Although they are satisfied with their job, their experience as explainers in scientific and cultural institutions does not last long. In our research about $84.9 \%$ of explainers have been working in this field for less than 5 years. This could either be the result of a peak in the industry in the last 10 years when the number of science museums and centres has increased, or could be attributed to what is happening in Europe [Richard, 2010], thus showing a dynamic aspect of this activity and indicating the existence of a high turnover of these professionals. It could also be linked to the fact that most of the young people who work as explainers receive scholarships, and that is not the career they will pursue.

As observed earlier, mediation requires knowledge and preparation. Therefore, it is fundamental for science centres and museums to offer professional training courses, as there are no technical or professional courses specific for the training of explainers. Obviously, it would be ideal that they could be trained before they start working as explainers. However, we observed that few science museums offer this type of preparation, and, in line with the study carried out in Europe, this trend takes place in most museums, as institutions do not organize professional training courses for explainers; when they do, in general they provide short duration courses [Rodari et al., 2006]. Thus, despite the role of explainers being considerably important in science museums and centres, little emphasis is attributed to their initial professionalization, which is taken care of by more experienced explainers and continuing development training courses that are provided mainly by science museums and centres, which, in Europe, takes place only in 11 out of 29 institutions involved in the European research [Rodari et al., 2006]. The lack of initial training might be tied to the the high turnover of explainers, as, for numerous institutions it would not be feasable to provide a professioanl training course to each new explainer.

As for the participation of explainers in the design of activities and/or exhibitions, surprisingly, in line with the answers provided by the respondents, Brazilian scientific and cultural institutions do take account of their explainers' opinions. We 
expected a similar result to that obtained by the European survey, whereby explainers declared that they are rarely involved in the development of activities and/or exhibitions [Rodari and Merzagora, 2007]. This is an interesting finding, as explainers directly interact with the public and therfore can significantly contribute to the production of the content of the exhibition. Moreover, as in Brazil mediation seems to be related to the growth of the individual, inviting explainers to participate to the development of content or projects contributes to this growth.

An important topic, generally debated during meetings or congresses about science communication, is that of science communication for disabled people. In South America, where social inclusion is emphasised, museums understand the importance of consolidating increasingly more inclusive scientific and cultural institutions. Some present projects to take care of this group of public. In Mexico, the Universum - the science museum of the National Autonomous University of Mexico - has a Social Inclusion Programme, whereby explainers learn sign language and strategies to provide the service to blind people and those affected by Down syndrome [Ruiz-Funes, 2008]. Besides, the project named "Aprender para Ensinar" ('Learn to Teach'), promoted by the Modern Art Museum in São Paulo, provides training for young deaf people willing to become explainers [Leyton, Lucena and Mussi, 2008]. Another significant work, dedicated to make science more accessible to young deaf people, is carried out by Vivian Rumjanek and her team. They show that obstacles are bigger than what one imagines, starting from the sign language itself, which does not include signs related to science [Almeida, Schiaffino and Rumjanek, 2014; Schiaffino and Rumjanek, 2012]. However, despite some sporadic efforts, the majority of scientific and cultural institutions do not provide any preparation for explainers to attend to this group of public. This is also confirmed by our data: a considerable number of explainers who answered our questionnaire $(62.6 \%)$ declared that they do not feel prepared to take care of disabled people. This data shows the urgent need to create structured and systematic strategies, so that science museums and centres are more inclusive.

Also, it was interesting to notice the concerns expressed by the explainers who answered our survey with regards to customer service. According to them, a explainer has to stimulate visitors' curiosity (instead of explaining scientific topics), in line with what stated by Pavão and Leitão [2007], who argue that "visitors need to leave with a bigger question than the one they brought". In practical terms, however, we observed an exaggerated school-type approach in science museums, with many importing the typical speech of the classroom to their own environment. In this scenario, an important challenge for Brazilian museums is to re-interpret their own social role: stop being a place where the public goes to learn and acquire information - a place of explanations. On the contrary, they should consolidate their role as an environment for debates about scientific and technological topics, where the different audiences take on the main role.

Finally, we would like to stress that this study is a first attempt to have a better understanding of who the explainers are in Brazil and, as with any pioneering work, it presents areas that need further investigation. However, we still believe that our study provides valuable information that can contribute to improve science communication in science centres and museums. Information about the explainers' profile, their practices and visions about their social activity - together with additional qualitative studies - can contribute to the creation of training and 
professional courses for explainers at a national level, as well as the development of environments for debates where these stakeholders can systematically interact, share experiences and work together. In particular, on the basis of our survey, we have designed a website to be published soon, with the purpose of providing free supporting documents for the practice of mediation and a virtual forum where experiences can be shared. In our view, such initiatives, together with others from different groups, can contribute to increase the social impact of explainers and science museums in Brazil.

\section{Translated by Sabina Brusemini}

\section{References}

Almeida, R.C.N., Schiaffino, R.S. and Rumjanek, V.M. (2014). 'Access and comprehension of information by profound deaf youngsters in Brazil'. Journal of media and communication studies 6, pp. 174-178.

Bonatto, M.P.O., Mendes, I.A. and Seibel, M.I. (2007). 'Ação mediada em museus de ciências: O caso do Museu da Vida'. In: Diálogos \& Ciência: mediação em museus e centros de ciência. Ed. by L. Massarani, M. Merzagora and P. Rodari. Museu da Vida/Casa de Oswaldo Cruz/Fiocruz, Rio de Janeiro, Brazil, pp. 47-54.

Brito, F., Ferreira, J.R. and Massarani, L. (2009). Centros e Museus de Ciências do Brasil 2009. Rio de Janeiro, Brazil: Associação Brasileira de Centros e Museus de Ciências/UFRJ. FCC. Casa da Ciência/ Fiocruz. Museu da Vida.

Costa, A.G. (2005). 'Should explainers explain?' JCOM 4 (4), C03.

Falk, J.H. and Dierking, L.D. (2000). Learning from Museus: Visitors Experiences and the Making of Meaning. California, U.S.A.: Altamira Press.

Ferreira, T., Bonfá, M., Librelon, R., Jacobucci, D. and Martins, S. (2008). 'Formação de monitores do museu de ciências da DICA: preparo além da prática'. In: XI Encontro de Pesquisa em Ensino de Física. (Curitiba, Brazil, 21st-24th October 2008).

Freitas, H.M.R., Janissek-Muniz, R. and Moscarola, J. (2004). Uso da internet no processo de pesquisa e análise de dados. Porto Alegre, Brazil: Lume Repositório Digital. Universidade Federal do Rio Grande do Sul. URL:

www. ufrgs.br/gianti/files/artigos/2004/2004\_147\_ANEP.pdf (visited on 19th February 2015).

Gomes, I. (2013). 'Formação de Mediadores em Museus de Ciências'. Dissertação (mestrado). Rio de Janeiro, Brazil: Universidade Federal do Estado do Rio de Janeiro, Museu de Astronomia e Ciências Afins.

Instituto Brasileiro de Geografia e Estatística (IBGE) (2010). Censo 2010. URL: censo2010. ibge.gov. br (visited on 19th February 2014).

Leyton, D., Lucena, C. and Mussi, J.Z. (2008). 'The "Learning in order to Teach" project and mediation in museums using Brazilian sign language (Libras'. JCOM 7 (4), C07.

Lima, V.M. and Pereira, K.F. (2010). ‘Processo de formação dos monitores do museu de anatomia humana e comparativa'. Itinerarius Reflectionis 8 (1), pp. 1-21.

Marandino, M. (2008). Educação em museus: a mediação em foco. São Paulo, Brazil: FEUSP.

Martin, M.S. and Tamez, M. (2008). 'Explainers - New energy for the museum'. JCOM 7 (4), C08. 
Massarani, L., Bauer, M.W. and Amorim, L. (2013). ‘Um raio X dos jornalistas de ciência: há uma nova "onda" no jornalismo científico no Brasil?' Comunicação $\mathcal{E}$ Sociedade 35 (1), pp. 111-129. DOI: 10.15603/2175-7755/cs . v35n1p111-129.

Ministério da Ciência e Tecnologia (2010). Percepção Pública da Ciência e Tecnologia no Brasil: Resultados da Enquete de 2010. Departamento de Popularização e Difusão da C\&T/SECIS/MCT; Museu da Vida/COC/Fiocruz. URL: http://www.mct.gov.br/upd \_blob/0214/214770.pdf (visited on 19th February 2015).

Mora, M.C.S. (2007). 'Diversos enfoques sobre as visitas guiadas nos museus de ciência'. In: Diálogos \& Ciência: mediação em museus e centros de ciência. Ed. by L. Massarani, M. Merzagora and P. Rodari. Museu da Vida/Casa de Oswaldo Cruz/Fiocruz, Rio de Janeiro, Brazil, pp. 22-27.

Moraes, R., Bertoletti, J.J., Bertoletti, A.C. and Sgorla de Almeida, L. (2007). 'Mediação em museus e centros de ciências: $\mathrm{O}$ caso do Museu de Ciências e Tecnologia de PUCRS'. In: Diálogos \& Ciência: mediação em museus e centros de ciência. Ed. by L. Massarani, M. Merzagora and P. Rodari. Museu da Vida/Casa de Oswaldo Cruz/Fiocruz, Rio de Janeiro, Brazil, pp. 55-66.

Pavão, A.C. and Leitão, A. (2007). Hands-on? Minds-on? Hearts-on? Social-on? Explainers-on! Ed. by L. Massarani, M. Merzagora and P. Rodari. Museu da Vida/Casa de Oswaldo Cruz/Fiocruz, Rio de Janeiro, Brazil, pp. 40-46.

Ribeiro, M.G. and Frucchi, G. (2007). 'Mediação - A linguagem humana dos museus'. In: Diálogos \& Ciência: mediação em museus e centros de ciência. Ed. by L. Massarani, M. Merzagora and P. Rodari. Museu da Vida/Casa de Oswaldo Cruz/Fiocruz, Rio de Janeiro, Brazil, pp. 67-73.

Richard, O. (2010). Report on the profile of European explainers, PILOTS Project, D3.3. URL: http://www.ecsite.eu/sites/default/files/project_docs/D3_3_ Report_on_the_profile_of_European_explainers_0.pdf (visited on 19th February 2015).

Rodari, P. and Merzagora, M. (2007). ‘Mediadores em museus e centros de ciência: Status, papéis e treinamento. Uma visão geral europeia'. In: Diálogos \& Ciência: mediação em museus e centros de ciência. Ed. by L. Massarani, M. Merzagora and P. Rodari. Museu da Vida/Casa de Oswaldo Cruz/Fiocruz, Rio de Janeiro, Brazil, pp. 8-20.

Rodari, P. and Xanthoudaki, M. (2005). 'Beautiful guides. The value of explainers in science communication'. JCOM 4 (4), C01.

Rodari, P., Merzagora, M., Conti, F. and Manzoli, F. (2006). 'Beautiful Guides - The role of professional explainers and young scientists in Science and society dialogue'. In: 9th International Conference on Public Communication of Science and Technology (PCST-9). (Seoul, Korea, 17th-20th May 2006).

Ruiz-Funes, C. (2008). 'Mediation within science centres and museums. The guides of Universum, México'. JCOM 7 (4), C04.

Schiaffino, R.S. and Rumjanek, V.M. (2012). 'A divulgação científica é surda aos surdos? Como o acesso ao conhecimento informal interfere na formação do conhecimento científico da população surda'. Tempo Brasileiro 188, pp. 79-96.

Tran, L.U. (2008). 'The professionalization of educators in science museums and centers'. JCOM 7 (4), C02.

Zana, B. (2005). 'History of the museums, the mediators and scientific education'. JCOM 4 (4), C02. 
Chrystian Carlétti is a teacher of Biology and Popularization of Science at Interactive Science Space (ECI) of Federal Institute of Education, Science and Technology of Rio de Janeiro (IFRJ). He is a PhD student in field of Bioscience and Health at the Institute Oswaldo Cruz / FIOCRUZ. He has a master in Science of same program. E-mail: chrystian.carletti@ifrj.edu.br.

Luisa Massarani is a Brazilian science journalist, $\mathrm{PhD}$ in Education, Communication and Governance of Science at the Institute of Medical Biochemistry/Federal University of Rio de Janeiro (UFRJ). She works at the Studies on Science Communication at Museum of Life where she has been conducting both practical activities and research in the area of science and society studies. She is also the Latin American coordinator of SciDev.Net (www.scidev.net). E-mail: lumassa@fiocruz.br.

\section{How to cite}

Carlétti, C. and Massarani, L. (2015). 'Explainers of science centres and museums: a study on these stakeholders in the mediation between science and the public in Brazil'. JCOM 14(02), A01_en. 